\title{
Management practices to enhance wildlife diversity of man-made fish ponds: the importance of the hydroperiod
}

\author{
J. Kloskowski ${ }^{(1), \star}$, M. Nieoczym ${ }^{(2)}$
}

Received July 6, 2015

Revised September 27, 2015

Accepted October 30, 2015

Key-words: aquaculture, anthropogenic wetland, ecosystem service, hydroperiod pond biodiversity

\section{ABSTRACT}

We examined correlates of amphibian and waterbird diversity related to management practices, with a focus on timing of flooding, at shallow ponds used for common carp Cyprinus carpio culture in Eastern Poland. The age of the stocked fish was a strong predictor of amphibian diversity, with higher scores obtained in ponds with young-of-the-year carp compared to ponds containing older (and larger) fish. Pond cover by emergent vegetation was positively related to diversity of both taxonomic groups. The timing of filling affected the taxonomic richness of the ponds; in contrast to ponds filled in early spring (March-early April), early breeding amphibian species were not recorded in ponds filled later (early May). However, amphibian diversity did not differ between earlyand late-flooded ponds. Early availability of filled ponds favored waterbird species richness and diversity, and the hydroperiod effect overcame the effect of fish age/size. Dissimilar responses to hydroperiod onset may reflect differences between amphibian and bird communities in the nature and strength of interactions with fish. Timing of flooding, which appears to be a neglected determinant of biodiversity in anthropogenic wetlands, should consider the breeding and migration phenology of wildlife species and the presence and population structure of fish.

\section{RÉSUMÉ}

Les pratiques de gestion pour améliorer la diversité de la faune des étangs piscicoles artificiels : l'importance de la hydropériode

\section{Mots-clés : aquaculture, zone humide d'origine anthropique,}

Nous avons étudié les liens entre la diversité des amphibiens et des oiseaux d'eau et les pratiques de gestion, avec un accent sur le calendrier des mises en eau, dans des étangs peu profonds utilisés pour la carpe commune Cyprinus carpio en Pologne orientale. L'âge des poissons déversés était un fort prédicteur de la diversité des amphibiens, avec des scores plus élevés obtenus dans les étangs avec des carpes jeunes de l'année par rapport aux étangs contenant des poissons plus âgés (et plus grands). La couverture de l'étang par la végétation émergente était

(1) Institute of Zoology, Poznań University of Life Sciences, Wojska Polskiego 71C, 60-625 Poznań, Poland 
service

écosystémique, hydropériode, biodiversité en étang positivement corrélée à la diversité des deux groupes taxonomiques. Le calendrier de remplissage affectait la richesse taxonomique des étangs; contrairement aux étangs remplis au début du printemps (mars-début avril), les espèces d'amphibiens à reproduction précoce ne sont pas présentes dans les étangs remplis plus tard (début mai). Toutefois, la diversité des amphibiens ne différait pas entre les étangs à mise en eau précoce ou tardive. La disponibilité précoce des étangs mis en eau favorisait la richesse et la diversité des espèces d'oiseaux d'eau, et l'effet de l'hydropériode dépasse l'effet de l'âge/taille des poissons. Des réponses inégales à la période de mise en eau peuvent refléter des différences entre les communautés d'amphibiens et d'oiseaux dans la nature et la force des interactions avec les poissons. Le calendrier des mises en eau, qui semble être un facteur déterminant négligé de la biodiversité dans les zones humides anthropiques, devrait prendre en compte la phénologie de la reproduction et de la migration des espèces de la faune, et la présence et la structure de la population de poissons.

\section{INTRODUCTION}

With the loss of natural wetlands on a global scale (Williams, 1990), anthropogenic aquatic environments, such as man-made ponds, have grown in importance for freshwater communities. In fact, they may be the only choice for aquatic wildlife in areas where natural wetlands no longer exist. Also, their function in supporting freshwater communities may differ substantially from that of natural ecosystems (Ma et al., 2009). Yet few studies have sought to explore how altering management of commercially exploited wetlands can improve their biodiversity performance (e.g. Elphick et al., 2010; Shulse et al., 2012).

Cyprinid ponds, with common carp Cyprinus carpio as the principal stock fish, have traditionally been a key sector of freshwater aquaculture in Asia and in mainland Europe, especially in the central and eastern part of the continent (Szücs et al., 2007). Considering the popularity of carp farming, integration of carp ponds into strategies of wildlife conservation deserves attention. Common carp is widely blamed for dramatic losses of diversity in natural ecosystems where the species has been introduced (Bajer et al., 2009; Matsuzaki et al., 2009). Moreover, in farmed ponds eutrophic conditions resulting from the input of nutrients to enhance fish yields are believed to be conducive to low biodiversity (Wezel et al., 2014). On the other hand, ponds used for carp culture have been identified as potentially vital breeding habitats for protected wildlife species, especially in regions poor in natural wetlands (Švažas and Stanevičius, 1998; Hartel et al., 2007; Kloskowski, 2010). The ecosystem potential of commercial carp ponds varies considerably depending on fish rearing practices and intensity of aquaculture (e.g. Broyer and Calenge, 2010; Wezel et al., 2014). Preservation of high ecological quality in carp ponds is not necessarily compatible with profit-oriented fish farming, not to mention conflicts arising from damage inflicted by wildlife (Guziur et al., 2003; Szücs et al. , 2007). However, owing to poor economic performance and market saturation, many fish farmers face the necessity of restructuring the use of pond resources and managing ponds for multiple purposes, which may include ecotourism and other ecosystem services (Szücs et al., 2007).

In Poland, ponds used for carp rearing are to some degree structurally uniform; the open, drainable water bodies are typically shallow to allow sunlight to penetrate to the bottom and stimulate pond productivity (Geldhauser and Gerstner, 2011). However, pond ecosystems differ in many aspects, such as which species are cultured, age and density of stocks, size (area), and hydrological regime, including the hydroperiod (the length of time a pond retains water). As in most other countries of Central and Eastern Europe, carp fishes are normally raised to marketable size in a three-year cycle. Year-classes are grown in separate ponds to optimally adjust farming practices to the production requirements specific for a given fish age (Opuszyński, 1987; Geldhauser and Gerstner, 2011). Pond permanency is dependent on the fish production system: fish can be kept in the same pond even for the entire growth 
period, but more commonly, the age-classes are transferred to wintering ponds in autumn while the rearing ponds remain drained until spring. Timing of pond re-filling varies; older age-classes can be restocked in early spring, while fish fry, which are sensitive to spells of inclement weather, are stocked later in the season (May-June) (Opuszyński, 1987). For wildlife, at the two extreme ends of the hydroperiod gradient, carp ponds are functionally equivalent to natural permanent waterbodies or to ephemeral wetlands, respectively (cf. Wellborn et al., 1996).

Our research goals were to identify management-dependent factors related to amphibian and waterbird diversity of age-structured carp ponds in Eastern Poland. Amphibians and birds commonly breed within carp ponds (e.g. Hartel et al., 2007; Broyer and Curtet, 2013) and could be used as flagships for wider conservation efforts or as indicators of wetland change (Weller, 1988; Walls et al., 2014; but see Guareschi et al., 2014). We have shown in previous papers that ponds with different-aged (-sized) fish provide habitats of different suitability for wildlife (Kloskowski, 2010; Kloskowski et al., 2010). Here, we particularly focused on the timing of flooding, a factor which has received little attention in research in both natural and constructed wetlands (Pechmann et al., 1989; Paton and Crouch, 2002; see also Kneitel, 2014). Separate stocking of carp age-classes and different hydroperiods allowed us to compare how various combinations of pond management regimes affect amphibian and waterbird diversity. The outcomes of our research should yield insights into pond management practices to support rich and diverse aquatic communities together with fish production.

\section{MATERIALS AND METHODS}

\section{> STUDY SYSTEM}

The research was conducted on carp farms located in an agricultural area with cropped fields, meadows and forests in Eastern Poland $\left(51^{\circ} 8-33^{\prime} \mathrm{N}, 22^{\circ} 15-23^{\circ} 16^{\prime} \mathrm{E}\right)$ (Figure 1). The ponds studied varied considerably in size, from 0.8 to 36.7 ha, but were roughly similar in depth profile (mean depths varying from 0.7 to $1.3 \mathrm{~m}$ throughout the fish growing season). The fish farms were situated in areas with varying geological backgrounds (Turski et al., 2008); the ponds were embedded in hydrogenic deposits and surrounded by soils varying from poor sandy soils with large amounts of clay content to more nutrient-rich, eroded loess deposits. The ponds differed in levels of nutrient enrichment by external runoffs, but the differences were to some degree evened out by extensive manuring, liming and increased supplemental feeding with cereal grains in less productive ponds.

As fish production was less than $1000 \mathrm{~kg} \cdot \mathrm{ha}^{-1}$, the ponds could be typified as extensive (cf. Horváth et al., 1992). The ponds were stocked with either young-of-the-year (0+, fry), one-year-old (1+) or two-year-old (2+) carp and occasionally with minor additions of supplementary fish, $0+$ wels Silurus glanis or pike Esox lucius. As the age-class corresponded to a specific size range, fish age could be considered equivalent to individual body size. Since individual weight at stocking was very small $(1.5-3.0 \mathrm{mg})$, standing biomass of $0+$ carp was practically negligible during the early study period. $1+$ fish were stocked at a body weight of $30-60 \mathrm{~g}$ and standing biomass of $98-390 \mathrm{~kg}$, and 2+ carp at about 140-300 $\mathrm{g}$ and 149-308 kg. Older fish were stocked shortly after ice-out (which normally occurs in March to early April in the study area), but carp larvae were not introduced into the ponds until May. Ponds supplied with river water via a network of ditches were filled shortly (within about one week) prior to fish stocking. Precipitation-dependent ponds began collecting water in winter, and therefore had earlier (and longer) hydroperiods. Most ponds were semi-permanently flooded, i.e. they were drained down in autumn and re-filled in spring. Some of the 1+ ponds were two-seasonal, holding fish continuously over two growing seasons after fry stocking. The ponds occurred in clusters, in which adjacent ponds were often separated only by levees 6-12 m wide. Within clusters, ponds with different-sized fish and different hydroperiods were spatially interspersed, and were mostly filled independently from each other. 


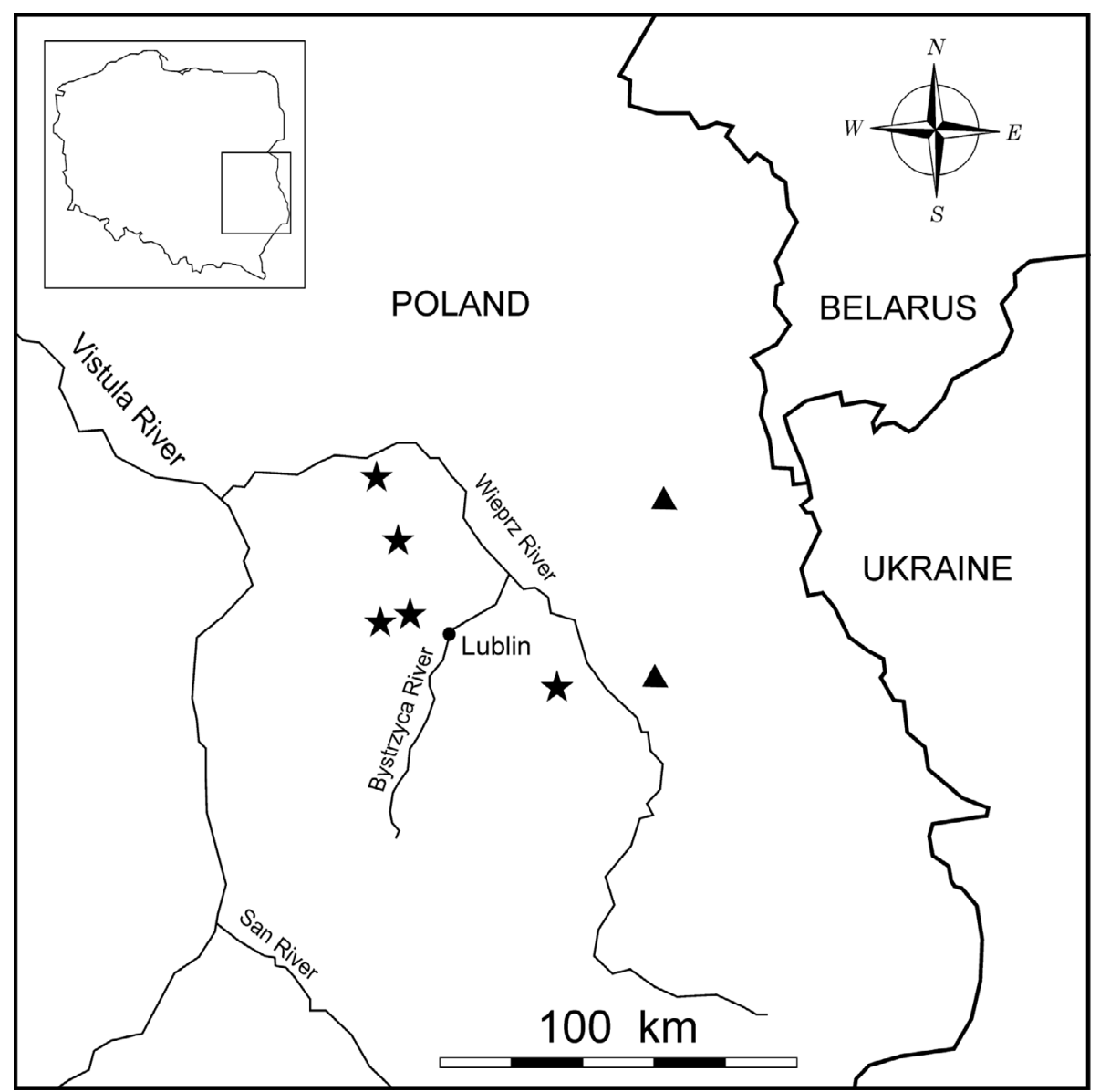

Figure 1

Map of pond study sites. Fish farms where only waterbirds were surveyed are represented by triangles, those where amphibians were surveyed as well, by stars. Inset shows location of the study area in Poland.

\section{$>$ AMPHIBIANS}

Each year from 2004 to 2008 10-17 ponds were sampled twice for relative amphibian densities. Altogether, we collected data from 68 ponds (five fish farms). Larval anurans and adult newts (newt larvae were very rare in the traps in contrast to adults) were captured during two sampling sessions, between 9 and 20 May, and between 3 and 10 June. The survey dates were chosen on the basis of a whole-season study in order to representatively sample both early and late breeding species. At each sampling session, ten 1-I activity traps with a funnel entrance (small opening: $23 \mathrm{~mm}$; large opening: $100 \mathrm{~mm}$ ) were installed in each pond at the interface between emergent vegetation and open water for approximately $24 \mathrm{~h}$ (see Kloskowski, 2010 for details of the trapping protocol). Most individuals were identified to species level except for the genus Pelophylax (P. ridibundus, P. lessonae and $P$. kl. esculentus) and the genus Rana (R. temporaria vs. $R$. arvalis). Individual taxon abundances per pond were expressed as maximum numbers of individuals recorded in any one sampling event. Taxa recorded from the study ponds are listed in Supplementary Table A1.

\section{$>$ WATERBIRDS}

In total, 104 ponds (7 fish farms) were studied from 2005 to 2009 (each year 6-35 ponds were surveyed). Bird surveys were carried out once about every 10 days from April to July. Birds (for the list of species see Supplementary Table A2) were censused using the standard 
round-count method by Koskimies and Väisänen (1991). The duration of the pond survey varied depending on pond area size and the number of birds present. During each survey, an observer walked around the ponds along the pond levees and birds were located and identified to species using binoculars and spotting scopes. For little grebe Tachybaptus ruficollis, water rail Rallus aquaticus, little crake Porzana parva and moorhen Gallinula chloropus, numbers of breeding territories were established using playback of tape-recorded calls at sunrise and at night (Bibby et al., 2000) on four different dates in May-June (minimum one night and one sunrise survey each month) at each pond. With the exception of playback surveys, bird counts were conducted between sunrise and late afternoon hours. The sequence of visitation of the pond complexes and of individual ponds was rotated at each visit. Numbers of mated pairs/breeding females/vocalizing males (territories) were estimated according to criteria proposed by Koskimies and Väisänen (1991), whereas timing of counts of individual species was scheduled following Ranoszek (1983), with slight modifications taking into account geographical differences in breeding phenology. For mallard Anas platyrhynchos we used data collected in April-May; for gadwall Anas strepera and pochard Aythya ferina midApril to mid-June; for tufted duck Aythya fuligula mid-May to mid-June; and for ferruginous duck Aythya nyroca and garganey Anas querquedula May-June. Mated pairs of mute swan Cygnus olor and greylag goose Anser anser were counted in April-June. Estimates of coot Fulica atra numbers were based on counts from mid-April to the end of July, and those of other rallids, grebes (little grebe, red-necked grebe Podiceps grisegena, great-crested grebe Podiceps cristatus and eared grebe Podiceps nigricollis) and little bittern Ixobrychus minutus from May to the end of July. Territorial bittern Botaurus stellaris males were counted in AprilJune. Duck abundance per pond was estimated either as the average number of males (for mallard) or of females (for other species). For species other than ducks and bitterns we used maximum numbers of observed pairs when consistent over at least three visits to the pond (flocks of adults were not considered); however, we used maximum numbers of broods (until the age of approximately four weeks) if they exceeded the numbers of pairs.

\section{>POND VARIABLES}

As independent variables, we included pond characteristics suggested to be of significance for amphibian or avian reproductive success and species richness in wetlands (e.g. Hudson, 1983; Vignoli et al., 2007; Shulse et al., 2012) and which in pond culture conditions depend on management operations. We classified the ponds into five types according to separate stocking of fish age-classes and culture-specific hydroperiod: early-flooded 0+ ponds (filled in March, exceptionally in the first two weeks of April), late-flooded 0+ ponds (filled between 1-15 May; ponds sampled for amphibians were filled prior to 7 May), all-year flooded $1+$ ponds (ponds containing water continuously since the previous growing season when stocked with fry), re-filled $1+$ ponds and 2+ ponds (both filled in March). Data on fish stocks (age, size range and standing biomass at stocking) and on pond hydroperiod were obtained from local fisheries.

Water quality and productivity were monitored in a subset of ponds representative for the entire study area throughout May-July 2006-2007 (Nieoczym and Kloskowski, 2014). The levels of chlorophyll a, turbidity and phosphate-phosphorus $\left(\mathrm{PO}_{4}-\mathrm{P}\right)$ were generally moderate during the study period, but tended to increase as the season progressed, with growing fish size and density and rising water temperatures. In July only, chlorophyll a values exceeded $100 \mu \mathrm{g} \cdot \mathrm{L}^{-1}$ in the presence of larger carp while turbidity in a few ponds reached about 20 NTU, an assumed threshold level of serious disturbance to macrophyte growth (Lougheed et al., 1998). Average values of $\mathrm{PO}_{4}-\mathrm{P}$ remained below $0.5 \mathrm{mg} \cdot \mathrm{L}^{-1}$ irrespective of fish size. Since the ranges of values indicative of nutrient status were narrow over most of the season, and our previous research found no strong relationship between nutrient concentrations in ponds and amphibian densities or composition of waterbird assemblages (Kloskowski, 2009; Kloskowski et al., 2010), we did not consider the effects of nutrient levels here. Emergent vegetation cover was expressed as the proportion of the surface area that was covered by emergent aquatic plants 
(range $0.05-0.77$ ). We did not control for the effect of submerged vegetation because during the early period after ice-out or after flooding (March-April, in late-flooded ponds early May as well) it was nearly absent from the ponds and was apparently functionally (as shelter or foraging habitat for wildlife) replaced at that time by the previous year's emergent vegetation beds (see also Hartel et al., 2007). The dry biomass of submerged macrophytes, measured in a subset of the ponds in early July 2005-2007, ranged on average from $51 \mathrm{~g} \cdot \mathrm{m}^{-2}$ in ponds with large, marketable fish to $90 \mathrm{~g} \cdot \mathrm{m}^{-2}$ in ponds with $0+$ fish; however, the differences were not significant (Nieoczym and Kloskowski, 2014). We calculated the proportional cover of pond shoreline (2-3 $\mathrm{m}$ buffer) by trees and bushes (range 0-0.99) and quantified the surrounding landscape composition within at least $30 \mathrm{~m}$ around each pond (the proportion of the shoreline adjacent to urbanized habitat, to forest patches, to arable fields, and to other ponds). Emergent vegetation cover and the last two variables were measured from digitized aerial photos using a geographic information system (QGIS 2.8 Wien) and, together with hydroperiod timing, were verified during field visits.

\section{> STATISTICAL ANALYSIS}

We compared the taxonomic composition of amphibian and waterbird assemblages between pond types using a nonparametric one-way analysis of similarity (ANOSIM; Clarke and Warwick, 2001). Post-hoc pairwise permutation tests followed each ANOSIM; the $P$-values were adjusted using a Bonferroni sequential correction. To select the species which were strongly associated with pond types, i.e. which contributed most to the taxonomic dissimilarities observed, we performed the Similarity Percentage procedure (SIMPER) with the PAST software package (Hammer et al., 2001).

We calculated taxonomic richness as the total number of amphibian or waterbird taxa recorded per pond. The Shannon-Wiener information index $\mathrm{H}^{\prime}$, was used as a measure of diversity. Since the use of Shannon values can produce biased estimates of the magnitude of between-group differences, we interpreted diversity in terms of the effective number of species (ENS), i.e., the Shannon-Wiener index was reported as exp $\left(H^{\prime}\right)$, as suggested by Jost (2006). We fixed the cases where taxonomic richness $=0$ (a few ponds with older carp where no amphibians were detected) to return ENS $=0$ for the zero-counts.

We evaluated the effects of habitat variables on amphibian and waterbird diversities and taxonomic richness using a generalized linear mixed modelling (GLMM) procedure. GLMMs are suitable for analyzing unbalanced data, where the sampling units are spatially clustered (here ponds within fish farms) and the study sites are sampled over several years, to take account of the non-independence of observations within study sites and years. In all models we considered fish farm (i.e. a spatial cluster of ponds) and year as random terms. The generalized linear component assumed a Poisson error distribution with a logarithm link. Among the inter-correlated predictors (Pearson coefficient, $p<0.05$ ), those considered more relevant based on better performing univariate models were retained for further model selection. Fish biomass density per pond was correlated with fish age due to very small individual size of $0+$ carp at stocking; therefore, we entered only fish age-class into the analyses, since it was a stronger univariate predictor. Similarly, the surrounding landscape variables were not related to diversity in univariate analyses (all $p>0.5$ ), therefore we entered only shoreline cover by trees and bushes into the models to minimize collinearity.

As amphibian and bird numbers can be related to pond area (Broyer and Curtet, 2013; Guareschi et al., 2014) and ponds holding older fish are typically larger in surface area than those with younger age-classes (Opuszyński, 1987), we included the logarithm of the pond area in the models as a so-called offset variable to adjust the dependent variable for pond size while allowing the use of the Poisson error structure (McCullagh and Nelder, 1989). We did not incorporate any interaction terms into the models because we did not presume that they would represent biologically meaningful hypotheses. Model simplification using backward selection was adopted. The use of stepwise model-reduction methods has been criticized in 
Table I

Poisson generalized linear mixed-effects model (fixed part) relating taxonomic richness and diversity of amphibians breeding in carp ponds to habitat variables.

\begin{tabular}{|l|c|c|c|c|c|c|}
\hline Response variable & Predlictor & Estimate & SE & Wald $\chi^{2}$ & df & $p$ \\
\hline & Fish age & & & 52.53 & 4 & $<0.001$ \\
& Early-flooded 0+ ponds & 0.000 & & & & \\
& Late-flooded 0+ ponds & -0.765 & & & & \\
All-year 1+ ponds & -2.349 & & & & \\
& 1+ ponds flooded in spring & -1.868 & & & & \\
2+ ponds & -2.822 & & & & \\
& Emergent vegetation & 1.857 & 0.662 & 7.87 & 1 & 0.007 \\
\hline \multirow{5}{*}{ Diversity } & Fish age & & & 37.23 & 4 & $<0.001$ \\
& Early-flooded 0+ ponds & 0.000 & & & & \\
& Late-flooded 0+ ponds & -0.485 & & & & \\
All-year 1+ ponds & -2.027 & & & & \\
& 1+ ponds flooded in spring & -1.614 & & & & \\
2+ ponds & -2.573 & & & \\
& Emergent vegetation & 1.354 & 0.757 & 3.20 & 4 & 0.079 \\
\hline
\end{tabular}

recent years (Whittingham et al., 2006; but see Murtaugh, 2009); however, we based inference on models with a small number of candidate predictors and only a single variable was dropped in all models (see Results). Also, full models including all predictor variables (fish age combined with pond hydroperiod, emergent vegetation cover, shoreline cover) yielded the same pattern of results as minimal models. Wald tests were used to estimate the significance of the fixed model terms. Standard errors of differences between all pairs were calculated. GLMM analyses were executed using GENSTAT v. 15.1. For all statistics, significance was accepted at $p<0.05$.

\section{RESULTS}

Both amphibian and waterbird assemblages differed among pond types (fish age combined with timing of pond filling; ANOSIM; $R=0.24$ and 0.21 , respectively, both $p<0.001$; 9999 permutations) (see also Supplementary Tables A1 and A2). Amphibian assemblages did not differ among ponds with $1+$ or $2+$ fish, but all other pair-wise comparisons were significant. Common toad Bufo bufo, spadefoot toad Pelobates fuscus and Rana frogs were the biggest contributors to dissimilarity (SIMPER, $21.8 \%, 21.3 \%$ and $14.1 \%$, respectively). In waterbirds, most pairwise comparisons were significant as well, except that the two types of 1+ ponds did not significantly differ and late-flooded $0+$ ponds did not differ from 1+ ponds filled all year. Coot, mallard and pochard contributed most to the dissimilarity observed in waterbird communities (SIMPER, $18.0 \%, 9.5 \%$ and $8.0 \%$, respectively).

For both taxonomic groups, the GLMM minimal models contained pond type (fish age combined with hydroperiod) and the ratio of emergent vegetation cover to open water (Tables I, II). Shoreline cover was dropped from all models (all $p>0.5$ ). Amphibian taxonomic richness and diversity was higher in $0+$ ponds than in ponds with older fish (Figure 2). Later-flooded 0+ ponds harbored fewer species than early-flooded 0+ ponds (Figure 2a); filling in May proved too late for these ponds to host Rana frogs and the common toad. However, diversity did not differ between the two categories of $0+$ ponds (Figure 2b). No significant differences in taxonomic richness or diversity were observed among ponds with older-age fish.

In waterbirds, taxonomic richness and diversity exhibited similar patterns, both indicating the importance of the timing of pond filling. Within the same age categories $(0+$ or $1+)$, earlierflooded ponds had higher scores than later-flooded ones. Moreover, unlike in the case of amphibians, no clear-cut difference was found between $0+$ ponds and those stocked with older-age fish: mean richness and diversity scores for $1+$ ponds filled year-round were intermediate and not significantly different from the values for early- and late-flooded $0+$ ponds (Figure 3). 


\section{Table II}

Poisson generalized linear mixed-effects model (fixed part) relating taxonomic richness and diversity of waterbirds breeding on carp ponds to habitat variables.

\begin{tabular}{|c|c|c|c|c|c|c|}
\hline Response variable & Predictor & Estimate & SE & Wald $\chi^{2}$ & $d f$ & p \\
\hline Species richness & $\begin{array}{c}\text { Fish age } \\
\text { Early-flooded } 0+\text { ponds } \\
\text { Late-flooded } 0+\text { ponds } \\
\text { All-year } 1+\text { ponds } \\
\text { 1+ ponds flooded in spring } \\
2+\text { ponds } \\
\text { Emergent vegetation }\end{array}$ & $\begin{array}{c}0.000 \\
-0.570 \\
-0.210 \\
-0.819 \\
-1.101 \\
0.776\end{array}$ & 0.333 & 52.53 & 4 & $<0.001$ \\
\hline Diversity & $\begin{array}{c}\text { Fish age } \\
\text { Early-flooded } 0+\text { ponds } \\
\text { Late-flooded } 0+\text { ponds } \\
\text { All-year } 1+\text { ponds } \\
1+\text { ponds flooded in spring } \\
2+\text { ponds } \\
\text { Emergent vegetation }\end{array}$ & $\begin{array}{c}0.000 \\
-0.5879 \\
-0.309 \\
-0.886 \\
-1.218 \\
0.735\end{array}$ & 0.365 & 4.07 & 4 & 0.047 \\
\hline
\end{tabular}
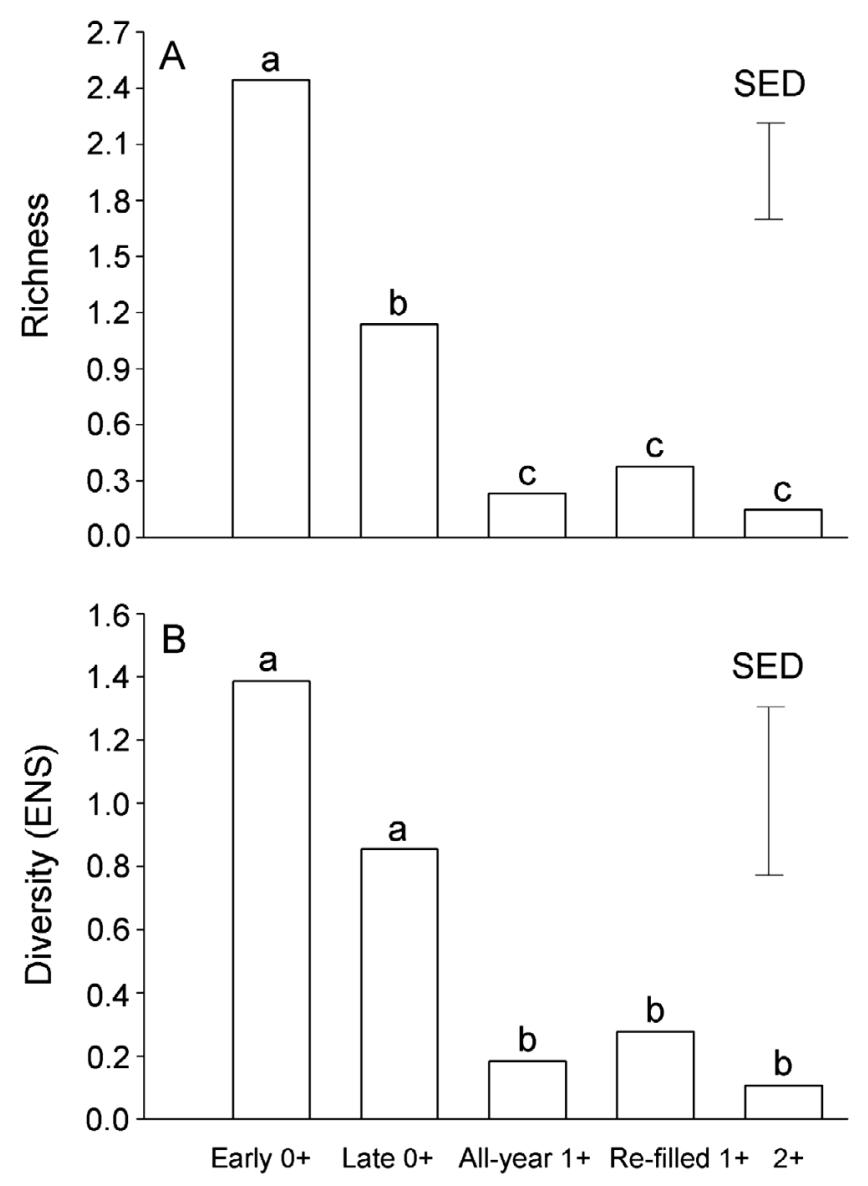

\section{Pond types}

\section{Figure 2}

Back-transformed GLMM predicted mean taxonomic richness (a) and diversity (b) of amphibian communities in the study ponds. SED, the average standard errors of differences (SED was not backtransformed). Unlike superscripts denote significant differences $(p<0.05)$. Early $0+$, early-flooded (March to early April) ponds with young-of-the-year fish; late 0+, late-flooded (May) ponds with youngof-the-year fish; all-year 1+, ponds holding water continuously since the previous summer, containing one-year-old fish; re-filled 1+, ponds with one-year-old fish; 2+, ponds with two-year-old fish (sample sizes, $n=13,14,12,14$ and 15, respectively). Ponds other than 0+ and all-year ponds were filled in March. See the main text for more detailed information on pond hydroperiods. 

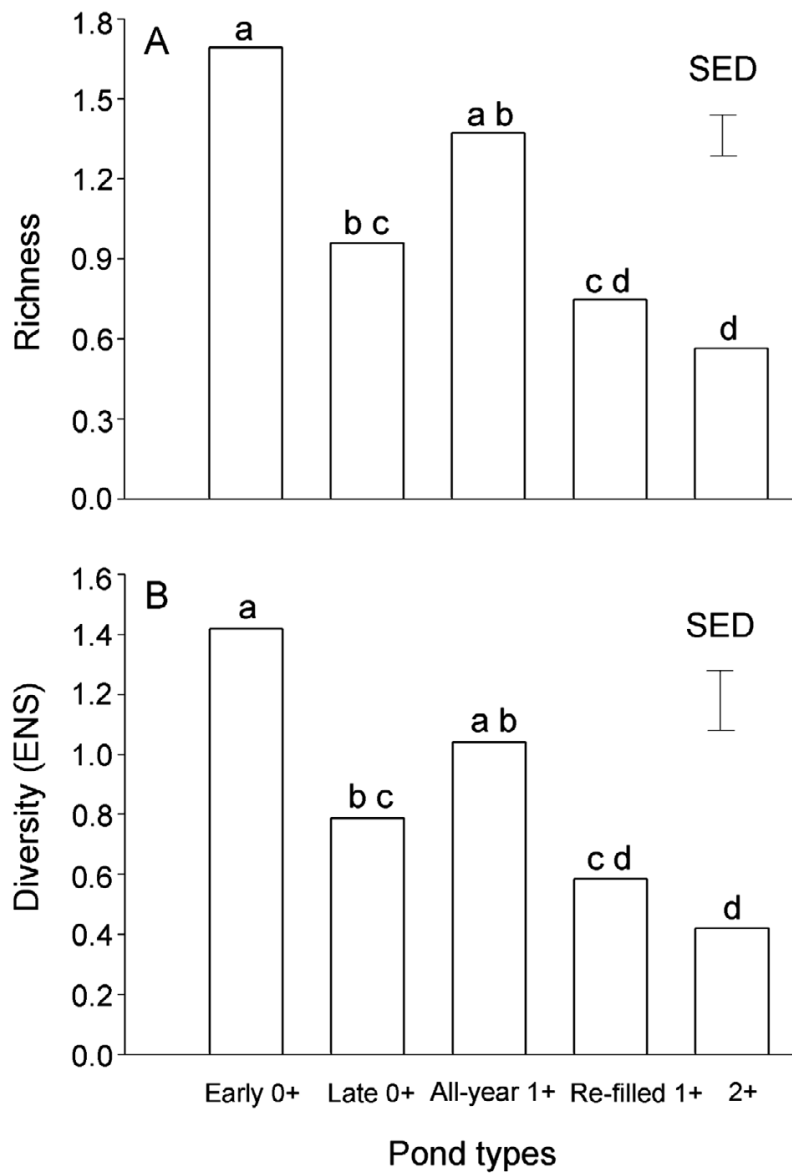

\section{Figure 3}

Back-transformed GLMM predicted mean taxonomic richness (a) and diversity (b) of waterbird communities in the study ponds. SED was not back-transformed. Abbreviations as in Figure 2. Unlike superscripts denote significant differences $(p<0.05)$. Sample sizes of ponds, $n=23,25,11,17,28$.

\section{DISCUSSION}

This study confirms our previous findings that age structure (individual size) of stocked fish can be a strong predictor of pond diversity (Kloskowski et al., 2010; Nieoczym and Kloskowski, 2015; see also Opuszyński, 1987). Greater biodiversity existed within amphibian communities that developed in ponds stocked with $0+$ fish than in those with older fish. In waterbirds, the differences between ponds holding fish of different ages were not so distinct. As stocking density was not independent of the fish cohort age, it was not considered in the analyses. However, the role of density in fish impact must not be overlooked, especially as it is involved in indirect effects on animal biodiversity in ponds via eutrophication processes, non-consumptive destruction or changes in the abundance and composition of aquatic macrophytes (e.g. Bajer et al., 2009; Matsuzaki et al., 2009; Weber and Brown, 2015). Hydroperiod timing affected amphibian taxonomic richness in ponds holding the youngest fish. Eastern European anurans, with the exception of the Pelophylax frogs and fire-bellied toad Bombina bombina, have a short reproductive season (Berger, 2000) and the delay in hydroperiod onset until May excluded early breeding species from reproduction in ponds filled so late. Nonetheless, these ponds did not differ from those flooded early in terms of taxonomic diversity. The reason could be that ovipositing females of some of the later-breeding species might prefer newly flooded waters due to the lower risk of predation by fish in such habitats or due to inter-specific segregation (e.g. Boone et al., 2002; Indermaur et al., 2010). Numerous patches of spawn of green toad Pseudepidalea viridis and tree frog Hyla arborea were detected in shallowly filled late $0+$ ponds (authors' personal observations). We did not 
find any distinct differences among 1+ ponds because ponds drained for the winter were already re-filled in March, allowing settlement by species which initiate breeding activities early. In waterbirds the importance of hydroperiod timing was more evident: ponds filled later had lower taxonomic richness and diversity than their early counterparts containing fish of the same age. Also, both indices did not differ between year-round $1+$ ponds and $0+$ ponds. Dissimilarities in between-pond distribution patterns between amphibians and waterbirds are likely to result from unlike character and intensity of interactions with fish. Carp-mediated eutrophication due to resuspension of nutrient-laden sediments or mobilization of nutrients from excretion (Lougheed et al., 1998; Matsuzaki et al., 2009; Weber and Brown, 2015) may have different effects on amphibians and waterbirds. Some amphibian species are reported to avoid habitats dominated by fish that pose a predatory threat to their eggs and larvae (Binckley and Resetarits, 2007; Kloskowski, 2011). By contrast, many waterbirds prey on fish, although carp vulnerability declines with body growth (Moser, 1986) and larger-size carp can diminish food availability for waterbirds through competition or deterioration of water clarity (Santoul and Mastrorillo, 2003; Broyer and Calenge, 2010). Also, interactions between fish and rallids or bitterns inhabiting emergent vegetation beds and rarely or never entering open water may be weak (Kloskowski et al., 2010). Thus, early availability of breeding waters, rather than fish presence, may be decisive in the choice of nesting habitat by these birds.

Both amphibian and waterbird diversity benefitted from abundance of emergent macrophytes in ponds. Emergent vegetation is vital for spawning (nesting) and foraging habitats as well as shelter against predators (Hudson, 1983; Hartel et al., 2007; Shulse et al., 2012). Broyer and Curtet (2013) found a curvilinear relationship between numbers of breeding ducks and the amount of emergent vegetation; densities of ducks and of epiphytic invertebrate biomass were highest when macrophyte cover was between $21 \%$ and $40 \%$. Besides prey availability issues, overabundant macrophyte cover may hinder diving birds associated with open water. However, emergent vegetation cover exceeding $40 \%$ is uncommon in commercial carp culture, as fish farmers usually strive to secure the largest possible fish production area (see below).

\section{> MANAGEMENT IMPLICATIONS}

Our results suggest that to effectively provide biodiversity services, management of manmade ponds should involve maintaining early hydroperiod onsets. This does not mean that to support rich amphibian communities cultured ponds should hold water year-round, because in "permanent" ponds significant populations of wild-grown fish and invertebrate predators will build up. Also, pond permanence favors development of a thick bottom layer of detritus, hampering production of benthos vital for fish feeding (Geldhauser and Gerstner, 2011). Ponds filled year-round can be used by migrating and wintering animals; however, note that drained aquaculture ponds provide non-breeding habitats for many birds as well (Švažas and Stanevičius, 1998). Given that in cold weather the period from egg laying to hatching may exceed two weeks (Berger, 2000) and no larvae of early-breeding anurans were detected in ponds filled in early May, these species require water in ponds at least a month earlier, optimally immediately after ice-out. Another positive outcome of earlier flooding would be accelerated growth of submerged vegetation, beneficial for some amphibians and waterbirds and for overall species richness in non-permanent ponds (Hudson, 1983; Rannap et al., 2009; Arthaud et al., 2013).

Hydroperiod onset issues are not trivial in human-managed wetlands, because timing of flooding is highly dependent on the type of wetland use (e.g. Azous et al., 2000; Jurajda et al., 2004; Koji et al., 2014). We believe that protection of the breeding habitat of pond wildlife has not sufficiently taken into account the phenology of immigration in amphibians and of spring arrival in birds (cf. Boone et al., 2002; Paton and Crouch, 2002; Johnson et al., 2010). Given the short reproductive period of most anurans and early commencement of breeding in some waterbirds in a temperate climate (Berger, 2000; Cramp and Simmons, 1977), even a 2-3 week difference in the time of pond filling can be critical for pond biodiversity. Our study 
design was fairly complicated, with crossed effects of fish and hydroperiod onset, but it allowed us to show that timing of inundation cannot be considered in isolation from other pond attributes. For example, in carp culture systems, filling ponds intended for older/larger fish as early as possible (so that they hold water for a longer period prior to stocking) is not justified by amphibian conservation because such a pond regime may act as a kind of ecological trap, given the adverse impact of large-sized carp on amphibian larvae (Kloskowski, 2010). However, most waterbirds will profit from early availability of nesting habitats. Compared to natural systems (Pechmann et al., 1989; Paton and Crouch, 2002), drawdown timing is of lesser concern for conservation, because carp are left in rearing ponds typically until at least September-October (Horváth et al., 1992), while emergence of metamorphs in amphibians and fledging in pond-breeding birds is largely terminated by this period.

\section{> COSTS OF BIODIVERSITY-FRIENDLY MANAGEMENT}

Practices aimed at conservation of pond biodiversity entail income losses. Normally, fish farmers attempt to synchronize the time of pond filling and stocking of vulnerable fry with periods of relatively high daily water temperatures and early stages of zooplankton succession, both of which promote rapid growth of fish larvae (Opuszyński, 1987; Horváth et al., 1992). Pond systems with unstable water supplies (e.g. from rainfall), such as our early-flooded $0+$ ponds, are usually filled for some weeks prior to stocking to secure water storage; thus, early flooding is a necessary and widely adopted management action. However, ponds with abundant water supply are filled as late as possible to preclude expansion of wild fish, and in fry ponds also to preclude development of vertebrate and invertebrate competitors and predators on fish larvae (Geldhauser and Gerstner, 2011; Guziur et al., 2003). Further research is required to estimate yield decline related to modification of hydroperiod; the early ponds studied suffered no apparent detriment to fish production (authors' unpublished data). To allow oviposition by anurans that naturally breed in ephemeral waters, such as the common frog Rana temporaria (Loman, 2002), a compromise solution could be to begin filling the ponds early but maintaining only a shallow layer of water. However, for waterbirds to settle, pond beds must be completely filled. Another point of conflicting interests between pond fisheries and conservationists is the amount of emergent vegetation in the ponds. Aside from the above mentioned benefits for wildlife, emergent vegetation ringing ponds protects pond levees from wave action and increases pond productivity (Geldhauser and Gerstner, 2011; Guziur et al., 2003). On the other hand, expansion of emergent vegetation comes at the cost of fish production area; it offers space for poachers and nuisance wildlife, such as otters Lutra lutra or cormorants Phalacrocorax carbo, and results in shading of the water column, increased water evaporation and depletion of nutrients from pond sediment (Guziur et al., 2003). Therefore, pond fisheries that commit themselves to such management requirements may demand compensation for adopting less intensive farming practices. In European Union countries, the strategy of the Common Fisheries Policy is to promote environmentally sustainable and knowledge-based aquaculture through protection and restoration of aquatic biodiversity. Accordingly, the European Maritime and Fisheries Fund may support aquaculture activities which include conservation and enhancement of biodiversity through compensation programs for the profit foregone (Regulation of the European Parliament 508/2014).

\section{> LANDSCAPE CONTEXT OF POND HABITATS}

We assessed diversity of individual ponds and their immediate surroundings (alpha diversities sensu Whittaker, 1972). We did not consider the broader landscape context (see Burgett and Chase, 2015), which might be crucial for amphibian conservation efforts, because our focus was on pond management, and the more distant surroundings of ponds may not be managed and influenced by the fish farms. For example, pond operators may control nutrient loading as part of pond management, but they take no responsibility for runoff water from agricultural surroundings, while pond productivity may interact with animal and plant species richness 
(Broyer and Curtet, 2011; Arthaud et al., 2013). At the landscape scale, fish farms are typically clusters of ponds with different-aged fish and varying hydroperiods. Ideally, closely spaced yet differently operated ponds might support various community types and complement each other to yield high beta diversities (Weller, 1988; Wezel et al., 2014). In amphibians, wetland complexes with a range of hydroperiods may facilitate temporal segregation to avoid interspecific competition or predation (cf. Vignoli et al., 2007; but see Indermaur et al., 2010). However, in the farmed area studied, amphibian assemblages were shown to exhibit a nested distribution among ponds; i.e., species-poor ponds harbored mainly the more common species (Kloskowski, 2010). This implies that ponds within a larger pond network may not necessarily complement each other for greater overall diversity. In view of the massive scale of pond aquaculture in Europe, adequate regulations aimed at protecting non-nuisance pond wildlife can substantially augment their existing habitats. However, conservation-oriented management strategies must be chosen carefully and tailored to local environmental conditions, to be conservation-effective as well as not to produce significant risks to fish production.

\section{ACKNOWLEDGEMENTS}

We are grateful to all of the fisheries managers who provided access to the ponds and information on fish stocks. Thanks also to the many volunteers who helped with amphibian sampling. This study was partially funded by the Polish Ministry of Science and Higher Education (MNiSW) Grant (2 P04 G 050 30).

\section{REFERENCES}

Arthaud F., Vallod D., Wezel A., Robin J. and Bornette G., 2013. Short-term succession of aquatic plant species richness along ecosystem productivity and dispersal gradients in shallow lakes. J. Veg. Sci., 24, 148-156.

Azous A.L., Reinhelt L.E. and Burkey J., 2000. Managing wetland hydroperiod: issues and concerns. In: Azous A.L. and Horner R.R. (eds.), Wetlands and urbanization: implications for the future. Lewis Publishers, New York, pp. 287-298.

Bajer P.G., Sullivan G. and Sorensen P.W., 2009. Effects of a rapidly increasing population of common carp on vegetative cover and waterfowl in a recently restored Midwestern shallow lake. Hydrobiologia, 632, 235-245.

Berger L., 2000. Płazy i gady Polski, PWN, Warszawa-Poznań, 148 p.

Bibby C.J., Burgess N.D., Hill D.A. and Mustoe S.H. 2000. Bird Census Techniques. Academic Press, London, $277 \mathrm{p}$.

Binckley C.A. and Resetarits W.J., 2007. Effects of forest canopy on habitat selection in treefrogs and aquatic insects: Implications for communities and metacommunities. Oecologia, 153, 951-958.

Boone M.D., Scott D.E. and Niewiarowski P.H., 2002. Effects of hatching time for larval ambystomatid salamanders. Copeia, 2002, 511-517.

Broyer J. and Calenge C., 2010. Influence of fish-farming management on duck breeding in French fish pond systems. Hydrobiologia, 637, 173-185.

Broyer J. and Curtet L., 2011. The influence of fish farming intensification on taxonomic richness and biomass density of macrophyte-dwelling invertebrates in French fishponds. Knowl. Manag. Aquat. Ecosyst., 400, 1-10.

Broyer J. and Curtet L., 2013. The influence of macrophyte beds on ducks breeding on fishponds of the Dombes region France. Wildfowl, 60, 136-149.

Burgett A.A. and Chase J.M., 2015. Landscape context influences the abundance of amphibians and the strength of their food web interactions in small ponds. Oikos, 124, 629-638.

Clarke K.R. and Warwick R.M., 2001. Changes in marine communities: an approach to statistical analysis and interpretation, PRIMER-E, Plymouth Marine Laboratory, Plymouth, 172 p.

Cramp S. and Simmons K.E.L., 1977. Handbook of the birds of Europe, the Middle East and North Africa: the birds of the Western Palearctic, Volume I. Oxford University Press, Oxford, 732 p. 
Elphick C.S., Taft O. and Lourenço P.M., 2010. Management of rice fields for birds during the nongrowing season. Waterbird, 33, 181-192.

Geldhauser F. and Gerstner P., 2011. Der Teichwirt. Ulmer, Stuttgart, 288 p.

Guareschi S., Abellán P., Laini A., Green A.J., Sánchez-Zapata J. A., Velasco J. and Millán A., 2014. Cross-taxon congruence in wetlands: assessing the value of waterbirds as surrogates of macroinvertebrate biodiversity in Mediterranean Ramsar sites. Ecol. Indic., 49, 204-215.

Guziur J., Białowąs H. and Milczarzewicz W., 2003. Rybactwo Stawowe. Oficyna Wydawnicza Hoża, Warszawa, $382 \mathrm{p}$.

Hammer $\varnothing$., Harper D.A.T. and Ryan P.D., 2001. PAST: Paleontological statistics software package for education and data analysis. Palaeontologia Electronica, 4, 1-9.

Hartel T., Nemes S., Cogalniceanu D., Öllerer K., Schweiger O., Moga C.I. and Demeter L., 2007. The effect of fish and aquatic habitat complexity on amphibians. Hydrobiologia, 583, 173-182.

Horváth L., Tamás G. and Seagrave C., 1992. Carp and pond fish culture, Fishing News Books. Oxford, $154 \mathrm{p}$.

Hudson M.S., 1983. Waterfowl production on three age-classes of stock ponds in Montana. J. Wildl. Manage., 47, 112-117.

Indermaur L., Schaub M., Jokela J., Tockner K., Schmidt B.R., 2010. Differential response to abiotic conditions and predation risk rather than competition avoidance determine breeding site selection by anurans. Ecography, 33, 887-895.

Johnson W.C., Werner B., Guntenspergen G.R., Voldseth R.A., Millett B., Naugle D.E., Tulbure M., Carroll R.W.H., Tracy J. and Olawsky C., 2010. Prairie wetland complexes as landscape: functional units in a changing climate. Bioscience, 60, 128-140.

Jost L., 2006. Entropy and diversity. Oikos, 113, 363-375.

Jurajda P., Ondračková M. and Reichard M., 2004. Managed flooding as a tool for supporting natural fish reproduction in man-made lentic water bodies. Fish. Manag. Ecol., 11, 237-242.

Kloskowski J., 2010. Fish farms as amphibian habitats: factors affecting amphibian species richness and community structure at carp ponds in Poland. Environ. Conserv., 37, 187-194.

Kloskowski J., 2011. Consequences of the size structure of fish populations for their effects on a generalist avian predator. Oecologia, 166, 517-530.

Kloskowski J., Nieoczym M., Polak M. and Pitucha P., 2010. Habitat selection by breeding waterbirds at ponds with size-structured fish populations. Naturwissenschaften, 97, 673-682.

Kneitel J.M., 2014. Inundation timing, more than duration, affects the community structure of Californian vernal pool mesocosms. Hydrobiologia, 732, 71-83.

Koji S., Ito K., Akaishi D., Watanabe K., Nomura S., Utsunomiya D., Pei H., Tuno N., Hidaka K. and Nakamura K., 2014. Responses of aquatic insect, terrestrial arthropod, and plant biodiversity to the V-furrow direct seeding management in rice fields. In: Usio N. and Miyashita T. (eds.), Socialecological restoration in paddy-dominated landscapes. Springer, Tokyo, pp. 173-195.

Koskimies P. and Väisänen R.A., 1991. Monitoring bird populations. A manual of methods applied in Finland, Zool. Mus., Finnish Mus. Nat. Hist. Univ. Helsinki, Helsinki, 144 p.

Loman J., 2002. Temperature, genetic and hydroperiod effects on metamorphosis of brown frogs Rana arvalis and $R$. temporaria in the field. J. Zool., 258, 115-129.

Lougheed V.L., Crosbie B. and Chow-Franser P., 1998. Predictions on the effect of common carp (Cyprinus carpio) exclusion on water quality, zooplankton, and submerged macrophytes in a Great Lakes wetland. Can. J. Fish. Aquat. Sci., 55, 1189-1197.

Ma Z., Wang Y., Gan X., Li B., Cai Y. and Chen J., 2009. Waterbird population changes in the wetlands at Chongming Dongtan in the Yangtze River Estuary, China. Environ. Manag., 43, 1187-1200.

Matsuzaki S.I.S., Usio N., Takamura N. and Washitani I., 2009. Contrasting impacts of invasive engineers on freshwater ecosystems: An experiment and meta-analysis. Oecologia, 158, 673-686.

McCullagh P. and Nelder J.A., 1989. Generalized Linear Models. Chapman and Hall, London, 532 p.

Moser M.E., 1986. Prey profitability for adult Grey Herons (Ardea cinerea) and the constraints on prey size when feeding young nestlings. Ibis, 128, 392-405.

Murtaugh P.A., 2009. Performance of several variable-selection methods applied to real ecological data. Ecol. Lett., 12, 1061-1068. 
Nieoczym M. and Kloskowski J., 2014. The role of body size in the impact of common carp Cyprinus carpio on water quality, zooplankton, and macrobenthos in ponds. Int. Rev. Hydrobiol., 99, 212-221.

Nieoczym M. and Kloskowski J., 2015. Responses of epibenthic and nektonic macroinvertebrate communities to a gradient of fish size in ponds. J. Limnol., 74, 50-62.

Opuszyński K., 1987. Freshwater pond ecosystems managed under a moderate European climate. In: Michael G.R. (ed.), Managed Aquatic Ecosystems. Elsevier, Amsterdam, 63-91.

Paton P.W.C. and Crouch W.B., 2002. Using the phenology of pond-breeding amphibians to develop conservation strategies. Conserv. Biol., 16, 194-204.

Pechmann J.H.K., Scott D.E., Gibbons J.W. and Semlitsch R.D., 1989. Influence of wetland hydroperiod on diversity and abundance of metamorphosing juvenile amphibians. Wetl. Ecol. Manag., 1, 3-11.

Rannap R., Lõhmus A. and Briggs L., 2009. Restoring ponds for amphibians: A success story. Hydrobiologia, 634, 87-95.

Ranoszek E., 1983. Test for methods of number estimation of breeding water birds. Not. Orn., 24, 177-201.

Santoul F. and Mastrorillo S., 2003. Interaction between fish and waterbird communities: a case study of two gravel pits in south-west France. Vie et Milieu, 53, 131-133.

Shulse C.D., Semlitsch R.D., Trauth K.M. and Gardner J.E., 2012. Testing wetland features to increase amphibian reproductive success and species richness for mitigation and restoration. Ecol. Appl., 22, 1675-1688.

Szücs I., Stundi L. and Váradi L., 2007. Carp farming in Central and Eastern Europe and a case study in multifunctional aquaculture. In: Leung P.S., Lee C-S. and O'Bryan P.J. (eds.), Species and system selection for sustainable aquaculture. Blackwell Publishing, Ames, pp. 389-413.

Švažas S. and Stanevičius V., 1998. Waterfowl of the large fish pond systems in Lithuania. Acta Zool. Lit., 8, 69-84.

Turski R., Uziak S. and Zawadzki S., 2008. Gleby. In: Uziak S. and Turski S. (eds.), Środowisko Przyrodnicze Lubelszczyzny. Lubelskie Towarzystwo Naukowe, Lublin, pp. 217-315.

Vignoli L., Bologna M.A. and Luiselli L., 2007. Seasonal patterns of activity and community structure in an amphibian assemblage at a pond network with variable hydrology. Acta Oecol., 31, 185-192.

Walls S.C., Waddle J.H., Barichivich W.J., Bartoszek I.A., Brown M.E., Hefner J.M., and Schuman M. J., 2014. Anuran site occupancy and species richness as tools for evaluating restoration of a hydrologically-modified landscape. Wetl. Ecol. Manag., 22, 625-639.

Weber M.J. and Brown M.L., 2015. Biomass-dependent effects of age-0 common carp on aquatic ecosystems. Hydrobiologia, 742, 71-80.

Wellborn G.A., Skelly D.K. and Werner E.E., 1996. Mechanisms creating community structure across a freshwater habitat gradient. Annu. Rev. Ecol. Syst. 27, 337-363.

Weller M.W., 1988. Issues and approaches in assessing cumulative impacts on waterbird habitat in wetlands. Environ. Manage. 12, 695-701.

Wezel A., Oertli B., Rosset V., Arthaud F., Leroy B., Smith R., Angélibert S., Bornette G., Vallod D. and Robin J., 2014. Biodiversity patterns of nutrient-rich fish ponds and implications for conservation. Limnology, 15, 213-223.

Whittaker R.H., 1972. Evolution and measurements of species diversity. Taxon, 21, 213-251.

Whittingham M.J., Stephens P.A., Bradbury R.B. and Freckleton R.P., 2006. Why do we still use stepwise modelling in ecology and behaviour? J. Anim. Ecol., 75, 1182-1189.

Williams M., 1990. Understanding wetlands. In: Williams M. (ed.), Wetlands, a threatened landscape. Blackwell Publishing, Oxford, pp. 1-41.

Cite this article as: J. Kloskowski and M. Nieoczym, 2015. Management practices to enhance wildlife diversity of man-made fish ponds: the importance of the hydroperiod. Knowl. Manag. Aquat. Ecosyst., 416, 34. 
Supplementary Table Al. Mean \pm SE densities ( individuals per10 traps) of larval anurans for five pond types. Early 0+, early-flooded ponds with young-of-the-year fish (filled in February-March); late 0+, late-flooded ponds with young-of-the-year fish (filled in early May); all-year 1+, ponds holding water continuously since previous summer, containing one-year-old fish; re-filled 1+, ponds with one-year-old fish (filled in February-March); 2+, ponds with two-year-old fish (filled in February-March). Sample sizes, $n=13,14,12,14,15$, respectively.

\begin{tabular}{|l|c|c|c|c|c|}
\hline \multirow{2}{*}{ Species } & \multicolumn{5}{|c|}{ Pond types } \\
\cline { 2 - 6 } & Early 0+ & Late 0+ & All-year 1+ & Re-filled 1+ & $2+$ \\
\hline Bombina bombina & $5.1 \pm 1.4$ & $3.6 \pm 1.2$ & 0 & 0 & 0 \\
\hline Bufo bufo & $18.8 \pm 15.7$ & 0 & $22.1 \pm 18.3$ & $34.5 \pm 17.9$ & $1.4 \pm 0.7$ \\
\hline Pseudepidalea viridis & $3.7 \pm 1.9$ & $10.6 \pm 4.9$ & 0 & 0 & 0 \\
\hline Hyla arborea & $11.5 \pm 3.7$ & $6.8 \pm 2.9$ & 0 & $1.1 \pm 0.9$ & $0.1 \pm 0.1$ \\
\hline Pelobates fuscus & $29.3 \pm 8.9$ & $7.1 \pm 2.5$ & $1.0 \pm 0.9$ & $2.6 \pm 2.5$ & $0.3 \pm 0.2$ \\
\hline Pelophylax spp. & $19.8 \pm 9.3$ & $8.6 \pm 1.9$ & $1.3 \pm 0.9$ & $4.8 \pm 4.3$ & $0.3 \pm 0.3$ \\
\hline Rana spp. & $18.7 \pm 5.0$ & 0 & $2.8 \pm 2.8$ & $7.0 \pm 5.3$ & $3.4 \pm 2.0$ \\
\hline Triturus cristatus & $0.5 \pm 0.2$ & 0 & $0.1 \pm 0.1$ & 0 & 0 \\
\hline Lissotriton vulgaris & $1.5 \pm 0.6$ & $0.9 \pm 0.8$ & 0 & 0 & 0 \\
\hline
\end{tabular}

Supplementary Table A2. Mean \pm SE densities (breeding pairs or territorial males per 10 ha) of waterbirds for five pond types. Sample sizes, $n=23,25,11,17,28$.

\begin{tabular}{|l|c|c|c|c|c|}
\hline \multirow{2}{*}{ Species } & \multicolumn{5}{|c|}{ Pond types } \\
\cline { 2 - 6 } & Early $0+$ & Late $0+$ & All-year 1+ & Re-filled 1+ & $2+$ \\
\hline Cygnus olor & $1.0 \pm 0.4$ & $0.2 \pm 0.1$ & $1.3 \pm 0.6$ & $0.7 \pm 0.2$ & $0.4 \pm 0.1$ \\
\hline Anser anser & 0 & 0 & 0 & $0.3 \pm 0.2$ & $0.6 \pm 0.2$ \\
\hline Aythya ferina & $5.6 \pm 1.1$ & $2.6 \pm 0.7$ & $3.5 \pm 1.4$ & $2.5 \pm 0.8$ & $2.5 \pm 0.5$ \\
\hline Aythya fuligula & 0 & 0 & 0 & 0 & $0.2 \pm 0.1$ \\
\hline Anas querquedula & $4.5 \pm 1.1$ & $2.8 \pm 0.9$ & $1.7 \pm 1.2$ & $0.7 \pm 0.3$ & $0.9 \pm 0.3$ \\
\hline Anas strepera & $0.3 \pm 0.3$ & 0 & 0 & $0.2 \pm 0.1$ & 0 \\
\hline Anas platyrhynchos & $4.6 \pm 1.2$ & $1.6 \pm 0.7$ & $8.3 \pm 2.4$ & $2.9 \pm 0.9$ & $3.4 \pm 0.5$ \\
\hline Tachybaptus ruficollis & $5.0 \pm 1.0$ & $3.0 \pm 0.7$ & $1.8 \pm 0.9$ & $0.6 \pm 0.2$ & $0.1 \pm 0.1$ \\
\hline Podiceps grisegena & $2.2 \pm 0.6$ & $0.3 \pm 0.1$ & $1.5 \pm 0.8$ & $0.4 \pm 0.1$ & 0 \\
\hline Podiceps cristatus & $0.8 \pm 0.4$ & $0.7 \pm 0.3$ & $4.3 \pm 2.0$ & $1.5 \pm 0.5$ & $0.7 \pm 0.1$ \\
\hline Podiceps nigricollis & $0.5 \pm 0.5$ & 0 & 0 & 0 & 0 \\
\hline Rallus aquaticus & $0.4 \pm 0.4$ & $0.2 \pm 0.1$ & 0 & $0.5 \pm 0.2$ & $0.4 \pm 0.1$ \\
\hline Porzana parva & $0.2 \pm 0.2$ & 0 & 0 & $0.4 \pm 0.2$ & $0.3 \pm 0.1$ \\
\hline Gallinula chloropus & $1.4 \pm 0.4$ & $1.3 \pm 0.3$ & $0.7 \pm 0.4$ & $0.5 \pm 0.2$ & $0.5 \pm 0.1$ \\
\hline Fulica atra & $18.6 \pm 2.0$ & $7.7 \pm 1.3$ & $10.1 \pm 1.8$ & $5.5 \pm 1.1$ & $4.9 \pm 0.6$ \\
\hline Botaurus stellaris & $0.3 \pm 0.2$ & 0 & $0.4 \pm 0.3$ & $0.6 \pm 0.2$ & $0.2 \pm 0.1$ \\
\hline Ixobrychus minutus & $0.1 \pm 0.1$ & 0 & $0.7 \pm 0.5$ & $0.6 \pm 0.4$ & 0 \\
\hline
\end{tabular}

